\title{
The contribution of virology to contemporary medicine*
}

\author{
SIR CHARLES STUART-HARRIS
}

\author{
Postgraduate Office, Faculty of Medicine, University of Sheffield
}

In the year 1636, eight years after the publication of his immortal work upon the circulation, William Harvey left London in the company of the Earl of Arundel and others on a mission to the Emperor Ferdinand. Europe at that time had been so ravaged by the 30 years' war and by epidemics of plague that a journey to Austria was both adventurous and hazardous. Nevertheless the travellers arrived safely at Linz and shortly afterwards Harvey was sent to Italy to acquire pictures for King Charles and to revisit Padua and Venice. He arrived at Treviso a few miles from Venice only to be thrown into a lazaretto on suspicion of infection because he had travelled through plague-stricken areas. A strict quarantine was in force for all travellers to Venice because of the severe epidemics in 1630, and Harvey's certificate testifying to his health was waved aside at Treviso. Inside the lazaretto Harvey remained in great discomfort, at first without even a bed, suffering from sciatica and chafing at the delay. His petitions for release were fruitless, he served the usual three weeks' quarantine, and his letters to Lord Denbigh at Venice were full of complaint (Keynes, 1966). Yet the quarantine of persons and goods coming from infected places was a measure advised by the Statutes of the College of Physicians (1630) and probably by Harvey himself in a futile attempt to restrict the spread of plague in London in the early seventeenth century.

Harvey was undoubtedly aware of the concept of contagion as it had been proposed by Fracastorius in the century earlier as the transmission of an infectious principle. Fracastorius (1546) classified the modes of contagion as by contact, through the air, and on clothing but Harvey rejected the latter mode. Yet in his great book De Generatione Animalium he described fertilization as a 'kind of contagion' in that contagious diseases such as leprosy and plague 'propagate their infection and beget themselves in bodies previously sound and untouched' (Harvey, 1653). He was thwarted in his attempts to define the seminal principle by the lack of a microscope, and it fell to van Leeuwenhoeck in 1686 to see for the first time live spermatozoa from the uterus of a bitch. The description of van Leeuwenhoeck's 'little animals', the bacteria and protozoa which he saw in pond-water, saliva, and faeces, was indeed the origin of the science of microbiology (Dobell, 1932). Yet the discovery of the existence of the 'little animals' did not lead to the microbial theory of disease until the works of Pasteur, Koch, and many others in the nineteenth century (Bulloch, 1938). The first successful laboratory transmission of a virus infection was probably that of Pasteur and others who infected rabbits intracerebrally with rabies in 1881 . Though viruses were filtered and their particles were seen, they remained as mysterious as the seeds of contagion postulated by Fracastorius until the twentieth century was well established.

\section{Virology as an INDEPENDENT SCIENCE}

Knowledge concerning the viruses has grown explosively since then. Earlier investigators regarded them as small bacteria which had become so intensely parasitic that they had no existence as free-living organisms outside their hosts' cells. But the work of Stanley (1935) and others on tobacco mosaic and other plant viruses which form semicrystalline arrays suggested that viruses were selfreplicating large molecules. Since then electron microscopy, ultracentrifugation and density gradient analysis, $x$-ray diffraction techniques, electrophoresis, and biochemical analysis have all been used to define the physical and chemical nature of virus particles. Lwoff in 1957 pointed to the essential difference between viruses and living micro-organisms in that the former possessed either ribonucleic acid (RNA) or deoxyribonucleic acid 
(DNA) but not both acids such as are found in micro-organisms. Thereby were separated the Rickettsiae and the Bedsoniae (Chlamydiae) from viruses. Lwoff formally defined viruses as 'strictly intracellular and potentially pathogenic entities with an infectious phase'. In addition to possessing only one type of nucleic acid, viruses, he said, multiply by replication of their genetic material; they do not grow or divide by binary fission and they derive the energy system necessary for the synthesis and construction of their substance from the host cells which they parasitize. Viruses, so Lwoff cries, are not independent organisms; they should be considered as viruses because viruses are viruses!

Acceptance of these views has been accompanied by a growing realization of the similarity of plant, animal, and insect viruses. Yet large differences exist in the size and complexity of their organization. The larger viruses possess several structural proteins and enzymes needed to build up their nucleic acid, differing from the polymerases of the host cell. Most viruses have a protein coat to protect them from destruction of their nucleic acid by host cell nucleases, and some possess an envelope of lipoprotein derived from host cell membranes as the particle is discharged from the host cell. There is a possibility that a few plant viruses possess no protein coat but are essentially naked nucleic acid, and a similar organization has been suggested for animal viruses not yet defined microscopically such as the 'slow' viruses.

The effects of the intracellular multiplication of animal viruses range from rapid destruction of their host cells to a form of infection in which the virus does not replicate yet the host cell multiplies. In addition the multiplication of infectious virus can occur in the absence of change in the host cell. These several modes of behaviour may be exhibited by a single virus in different host-cell systems so that pathological effects are not a sound basis for virus classification. Instead virologists prefer the chemical and physical structure of the particle, its size and type of nucleic acid. Such a classification has brought the rhinoviruses of the human common cold into juxtaposition with foot-and-mouth disease virus, and human influenza and mumps viruses have become close cousins (Andrewes and Pereira, 1972).

We live today in the era ushered in by Enders, Weller, and Robbins (1949) when they showed how to cultivate the virus of poliomyelitis in test-tube tissue cultures. The virus formerly thought to be so fastidious in its cultural requirements as to need nerve cells was thus grown in vitro in that most lowly of all cells - the fibroblast. The ability thus to cultivate human viruses outside the animal body has conferred upon medicine the power to isolate the agents of common infections and to interfere with the spread of disease by immunization with specific vaccines. The successful campaign wit/ poliovirus vaccines has been followed by achievements against measles and rubella, though with? other virus diseases there have been disappointe ments. This is particularly true for the acutê infections of the respiratory tract, ranging from the common cold to bronchiolitis in which the multi plicity of viruses concerned militates against the success of specific vaccines. Attention has conse $=$ quently turned towards the possibility of chemo? therapy or chemoprophylaxis to inhibit virus $\overrightarrow{-}$ multiplication but so far success has been limitedo

Meanwhile analysis at a sub-cellular level has revealed the remarkable sequence of events which? follows penetration of the viral nucleic acid into the host cell. The usual sequence leading to the releaseof infectious virus particles appears to be one in which the virus has genetic independence from the cell and controls its own destiny. Yet in the lysogenic system seen in the bacteriophage-bacteriunas relationship, the virus nucleic acid appears to fuse with that of the bacterium until released by some change in the host to become vegetative 'phage once again. An analogy for mammalian viruses exists in certain tumour viruses such as the monkeg $\mathrm{SV}_{40}$ virus, mouse polyoma virus, oncogenic humaris adenoviruses, and the E-B virus of Burkitt lym phoma (Nonoyama and Pagano, 1973). The fact that the viral nuclear fragments of certain of these tumour viruses can in certain circumstances become activated so as to direct the replication and release of fresh infectious particles indicates the genetic independence of the virus even in this intimate relationship. Thereby the apparent similarit between fertilization and infection, which was pictured by Harvey, is abruptly ended. For the virus is a genetic intruder, the spermatozoon genetic partner.

Speculation concerning the mode of origin of viruses arouses ancient controversies. Though it is usually held that existing viruses have evolved from pre-existing ones, as for micro-organisms as at whole, the possible origin of a virus from living matter of a type entirely different from itsel cannot be dismissed. Burnet wrote in 1973 that he could visualize that a curious genetic acciden might occur within a cell's nucleus, involving loss of gene control and separation of a part of the cell's genetic material. If favoured by suitablê environmental conditions such a fragment migh maintain its independence as a 'pro-virus' or 'virogene' within the cell. He even spoke of the possible origin of the first influenza virus in this manner whereby a single initiating accident gave्ह 
rise by its progeny to all past and present strains. As will later be shown, this heterodox view concerning influenza virus is one among many called upon to explain the origin of this chameleon of viruses.

But the concept of virogene is no longer a theory if the recovery of the C-RNA leukaemia viruses from apparently normal animal embryonic cells is accepted (Todaro, 1973). Huxley (1870) thought that viruses such as vaccinia virus might represent a form of Heterogenesis termed by him Xenogenesis, the generation of something foreign from living matter. One hundred years later it seems that views concerning the origin of at least some viruses may have revived a belief in spontaneous generation. Huxley analysed Harvey's views on this subject as revealed by the Exercitationes de Generatione and concluded that he may have believed in spontaneous generation as did his contemporaries. His writings expressed the conviction that all living things arise from some sort of primordium or egg (Ex ovo omnia) though he did not state that the latter must proceed from a living parent. How astonished he would have been in the current state of belief concerning the origin of the virus, the enemy of organized life.

IMMUNIZATION AND THE CONTROL OF INFECTION

When Jenner and Pasteur took the first steps towards the practice of immunization, it is doubtful whether either thought vaccines could bring about the control of the spread of human infection. The use of variolation and Jenner's observations upon cowpox in 1798 suggested the possibility of mimicking harmlessly natural disease and thus of conferring upon the individual an artificially acquired resistance. Yet control of smallpox in the community is now known to depend much more upon breaking the chain of transmission of infection than upon the existence of a high proportion of immune persons. Virology has indeed played a decisive role in the control of some virus infections partly through the elaboration of safe and effective vaccines and partly by the collection of sound epidemiological data. Isolation of viruses from patients, healthy contacts, and extrahuman sources of infection has been coupled with serological surveys on persons of different ages and in many different countries. The extension of that which Paul (1938) named 'clinical epidemiology' by virological techniques has thus brought to fruition effective control of the clinical manifestations of some diseases in a manner scarcely conceivable forty years ago. This is best exemplified by the history of poliomyelitis.

\section{Poliomyelitis}

Poliomyelitis is certainly an ancient disease yet in its epidemic form it is a modern phenomenon. The first clinical account of patients recognizably suffering from poliomyelitis is usually attributed to Heine of Stuttgart whose monograph appeared in 1840. However Heine had read of a series of four patients in the small town of Worksop near Sheffield previously reported by John Badham in the London Medical Gazette (Badham, 1835). It was not until 1890 that Medin gave an account of epidemic poliomyelitis in Sweden and soon afterwards the first New World epidemic was reported from Vermont in 1894 (Paul, 1971). From the turn of the century onwards increasingly large epidemics, predominantly in infants, occurred in Scandinavia, the United States of America, and Australia. Yet large-scale epidemic poliomyelitis in the British Isles was delayed until toward the end of the second world war. Then came the epidemics of 1947 and 1950 and subsequently, which clearly indicated that experience was following along the lines of that in the USA, where not only children but adults were increasingly affected. The dreaded involvement of the brain stem in the bulbar form of the disease also introduced a new threat to which the only answer then available was the iron lung.

Landsteiner and Popper's (1908) classic transmission of the disease to monkeys using human spinal cord was the first proof that poliomyelitis was an infective disease. Obsession with the nervous system manifestations probably delayed recognition of the significance of Kling, Pettersson, and Wernstedt's work in Sweden in 1912 upon the recovery of virus from the intestinal contents. Thus the true epidemiology of the disease was not grasped until Trask, Vignec, and Paul at Yale recovered poliovirus from the stool in 1938. The ability to study the pathogenesis of poliomyelitis by tissue culture techniques also led to a new insight into the involvement of the central nervous system from the blood (Horstmann, 1952) and thus to the hope that it might be possible to overcome the pathological consequences of infection. In my first Croonian lecture in 1962 (Stuart-Harris, 1962) I described some of the work upon pathogenesis and the epidemiology of poliovirus infection and I shall not repeat it now. It must, however, be emphasized that the introduction of poliovirus vaccines took place against the background of a formidable clinical threat to the populations of developed countries which had, as a consequence of modern sanitation, become subject to repeated epidemics affecting adults as well as children. 
The promise of the effectiveness of Salk vaccine so ably demonstrated by the clinical trial organized by the late Thomas Francis and his team at Ann Arbor (Francis et al., 1957) was nearly dashed by the unfortunate occurrence of disease due to failure of inactivation of the virus in one particular vaccine. Yet it was the application of the Salk vaccine which first led to the decline of the disease in the USA and in Britain and it is a matter of conjecture whether, had countries persevered with its use, effective control over poliomyelitis would have been obtained. Sweden's record shows indeed that the Salk vaccine alone can control the disease in a small country with high standards of hygiene and rates of acceptance of vaccine.

In Britain, the oral live attenuated vaccine prepared from Sabin's viruses began to be used from 1962 onwards, and it soon supplanted the Salk vaccine, largely on the grounds of acceptability and ease of administration. These were undoubtedly important in the achievement of a high rate of immunization estimated at $80 \%$ in England and Wales in recent years. This has been accompanied by a decline in the disease to a very low level (Fig. 1). Throughout this period a careful surveillance of poliomyelitis and of all illnesses leading to

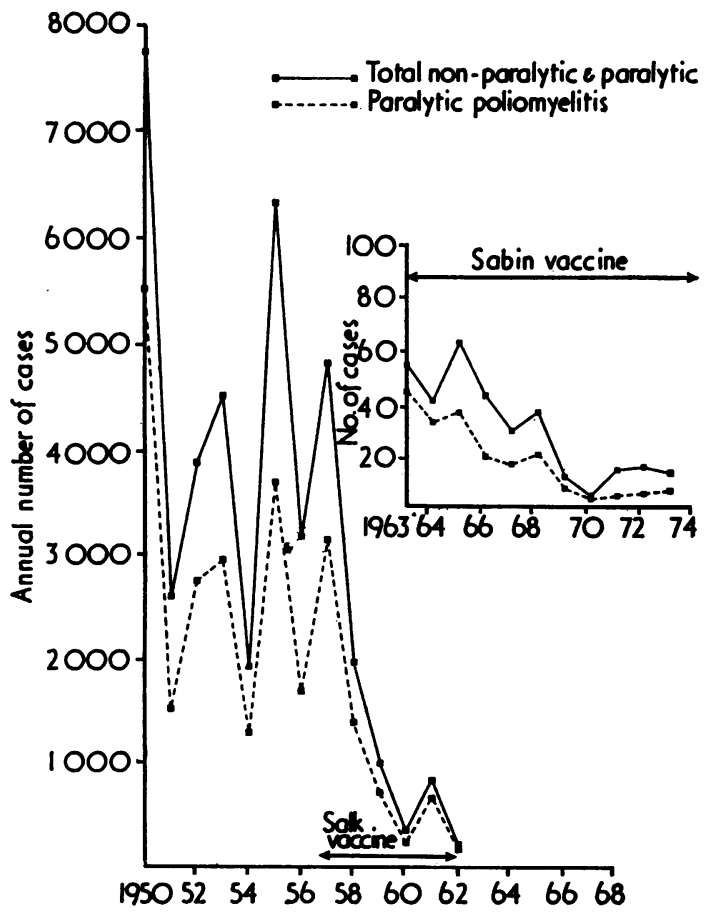

FIG. 1. Annual notifications of poliomyelitis in England and Wales 1950-73. recovery of poliovirus has been maintained bo the Public Health Laboratory Service (Miller, Reic and Diamond, 1970). The polioviruses recovered in the laboratory of recent years have largelf possessed the cultural properties of attenuated viruf strains (Cossart and Whitehouse, 1973). They were probably derived from the vaccine viruses which. infect the throat and are excreted in the faeces? Apart from the occasional importation of viruleme virus from abroad and its sporadic activity in the community, transmission of natural wild polio virus appears largely to have ceased in Britain.

The control thus gained over poliomyelitis hass not been free from hazard. Paralytic illnesse: occurring soon after immunization in recipients of vaccine or their contacts have been recorded in many countries as "vaccine-associated poliomyelitise? The use of oral vaccine during outbreaks or in contacts of single cases of paralysis has meant that some persons received vaccine who were at the time incubating infection by wild polioviruses. Accord ingly, some of the viruses which have been recovered from vaccinated persons with paralysis havo possessed the biological markers of virulent viruses but others have exhibited the markers of attenuafedy vaccine strains. As some natural viruses recoveded before the use of live vaccines were biologicinle similar to attenuated viruses, recovery of the lafte from vaccinated persons does not prove the origin. But it is a fact that the vaccine viruses caf alter biologically during their multiplication in man, and this has led to a suspicion that they ma $\vec{\otimes}$ also recover virulence. Curiously enough, type II strains have predominated among polioviruses recovered from vaccine-associated cases, whereas. contact cases have more often yielded type $1 \mathbf{5}$ strains (Smith, 1974), and this difference is unexplained. The incidence in England and Wales of paralysis in recipients of Sabin vaccine has been. estimated by Miller et al. (1970) to be one per milliop doses, and if only illnesses with residual paralysis are counted the figure is one per four millioif doses of vaccine. This risk has to be counterbalanced against the sparing of children and adults front. disease. As poliomyelitis due to virulent virusి continues to occur in many countries, especially in the tropics, the continuation of immunization in the British Isles seems to be essential.

The recipe for successful control of poliomyelitis in developed countries appears to depend on threes or more ingredients. The stability of the antigen $\$$ of the three serotypes of polioviruses favours the production of a durable immunity. Secondly, the live, though not the inactivated, vaccine renders the alimentary tract resistant to re-infection bo poliovirus at least for some months. Thus th 
liberal use of oral vaccine in the contacts and neighbours of each paralytic case, as has been practised in Britain since 1963, has an excellent chance of blocking the transmission of virulent virus. Thirdly, the capacity of the live vaccine to infect, to multiply, and to be excreted must favour a gradual replacement of virulent by attenuated viruses in the community. It is often stated that control over disease results from basic immunization of children, yet serological studies in Britain have shown that a proportion of children are devoid of serum antibodies to one or more serotypes of poliovirus (Skelton, Schild, and Stuart-Harris, 1966; Reid et al., 1973). Unless therefore basic immunization is supported, as indicated, by blocking transmission of virulent virus from those with paralysis, outbreaks may continue to occur. The failure to control poliomyelitis in Africa and developing countries elsewhere shows that success is not guaranteed by immunization alone, though special reasons may exist for vaccine failure in tropical countries, such as the infestation of children with other enteroviruses. Meanwhile it is plain that the threat of epidemics of poliomyelitis in developed countries has been overcome.

\section{MeAsles}

The disease produced by the measles virus and the means now available to counter it present many contrasts with poliomyelitis. Measles is an ancient disease whose description is usually attributed to Rhazes in the tenth century. In the seventeenth and eighteenth centuries it had an unenviable reputation in Britain, and in Africa today it causes a considerable infant mortality (Morley, 1969). Its potential for causing illness in a susceptible population was demonstrated by the classical epidemic of the Faroe Islands in 1846 described by Panum (1940) and attributed to the lifting of quarantine which had for 65 years kept the islands free from measles. The epidemic of 1846 spared those involved in the previous epidemic of 1781 but caused 6000 cases and 102 deaths. The case fatality rate was disproportionately heavy in babies under 1 and adults over 60 years.

A somewhat similar epidemic occurred in Greenland in 1951 with an almost total involvement of the population of some districts but the mortality was lower than in the Faroes, perhaps because of the use of penicillin and of serum prophylaxis. In Africa today malnutrition, though often blamed for the severity of measles, often follows it, and Heyworth (1973) noted that recently severe measles in the Gambia afflicted some well-nourished children who nevertheless died.
In Britain the present mortality from measles is relatively unimportant, and those who die have nearly all exhibited congenital defects including immunological abnormalities. Yet the disease has caused massive biennial epidemics in infants and children both before and since the second world war. These measles epidemics interrupt the lives of children and furnish a large demand for medical care. They are accompanied by many complications most recently studied by Miller (1964) in an enquiry by the Public Health Laboratory Service. Three-fifths of the 53000 persons notified as measles who were surveyed in 1963 were less than 5 years of age. A total of 3530 complications were recorded among which respiratory illnesses predominated. But there were 61 instances of encephalitis or impaired consciousness, giving a rate of 1.2 per 1000 cases, similar to the previous estimates of Miller, Stanton, and Gibbons (1956) and Tyler (1957). As less than half of the patients surveyed with encephalitis were admitted to hospital in 1963, the others probably suffered transient disturbances such as convulsions, which in measles may perhaps be triggered by the pyrexia of the disease. Even at a rate of 0.5 per 1000 the measles epidemic of 1963 probably caused 170 children to suffer from neurological illnesses requiring admission to hospital.

This then is the background to the new virology of measles and the introduction of measles vaccine. The virus, though known previously by means of transmission experiments, was first cultivated in tissue cultures by Enders and Peebles in 1954. It was adapted to fertile hen's eggs, then to chick embryo cells, and by repeated passage in the laboratory it became progressively attenuated in virulence and suitable for use as a vaccine in children. Enders and others (1960) described the first attenuated measles vaccine, and Schwarz (1964) further attenuated one of Enders original strains. Two vaccines, one inactivated and the other live attenuated virus, were tested for their protective power by large-scale trials in Britain organized by the Medical Research Council Measles Vaccine Committee (Reports of the Measles Vaccines Committee, 1966, 1968). The inactivated vaccine appeared to interfere with subsequent antibody responses to the live attenuated strain, and this alone gave satisfactory results and few reactions. Protection over the nine years since the trial has been reported to be good and sustained though a trickle of cases occurs in those previously immunized (Reports of the Measles Vaccines Committee, 1971, 1972).

Large-scale use of the vaccine in Britain began in May 1968 when vaccines became available for 
infants in the second year of life and also for older children who had never experienced clinical measles. By the end of the year more than 750000 children had been immunized, and though the campaign was temporarily checked in March 1969, the effect of the immunization of probably one and a quarter million children was profound. The epidemic which would have been expected in the winter of 1968-69 did not occur, and though the summer incidence of measles in 1970 was slightly greater than usual, there has been no return of winter epidemics such as those experienced before 1968 (Fig. 2). This consequent

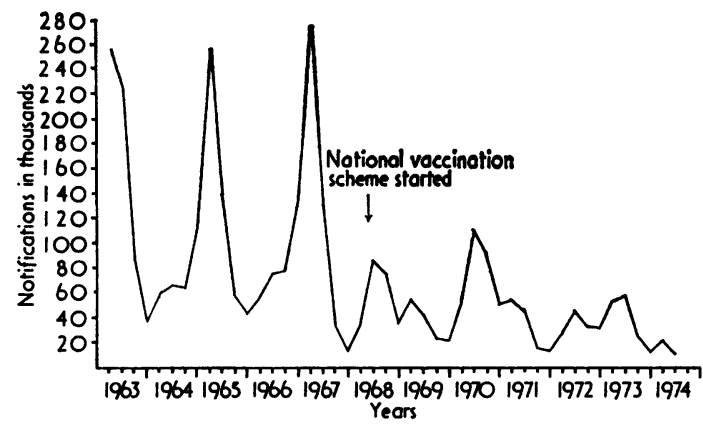

FIG. 2. Quarterly notifications of measles in England and Wales, 1963-74. (Courtesy of Dr. W. Dunnet, Department of Health and Social Security).

sparing of children from the complications of measles has to be offset against the effects of the vaccine. These have not been negligible. Fever and a slight rash occur in a small proportion of immunized children, and in those under 2 years of age convulsions sometimes accompany the fever. The less attenuated measles vaccines produce a higher incidence of such reactions than that encountered with the Schwarz strain. A more worrying feature is the reporting of neurological illnesses termed 'encephalitis'. These have varied greatly in clinical type and have proved difficult to investigate retrospectively. More were reported before 1970 than subsequently but the highest incidence of 3 per 100000 immunizations was far lower than that of the neurological complications of natural measles. As with convulsions, these nervous system effects were commoner in children before their second birthday than subsequently so that a delay in administration of vaccine until after this date is advisable.

At the present time it is difficult to predict how effective measles vaccine will prove to be in the elimination of the disease. Experience in the USA and in Canada is similar to that in Britain, and a reduction of prevalence to a relatively low levep has been achieved through the immunization of susceptible children. Yet Sutherland and Fayero (1971) have estimated that each year 80 to $90 \%$ of susceptible children must be immunized if measles? is to be controlled. Roden (1973) found that onle about $40 \%$ of British children born in 1968 were. immunized by 1971 so that present efforts are clearly inadequate. There is the further problem of $₫$ possible waning of immunity and a need fofs re-immunization but information concerning the basis for this is lacking. There is also a need to re-examine the mode of contagion of measles and its spread within the family using specific viro? logical techniques. On the analogy with smallpo it may be necessary to use vaccine strategicallit when the natural incidence falls to the level where focal outbreaks can be identified. Even so, $\vec{t}$ cannot be denied that already a significant advance has occurred in the prevention of measles in children and that this has been the outcome of the application of specific immunization.

\section{Congenital Rubella}

Since the discovery by Gregg in Australiaôio 1941 that there was an association between matexpat rubella and congenital cataract and heart diserse knowledge concerning congenital rubella thas developed steadily. The size of the problem is nof large. The national surveillance programme if Great Britain organized by Professors Dudgeol and Smithells gave an estimate that perhaps $25 \overline{0}$ virologically confirmed cases of congenital rubella occur during a year (Table) (Dudgeon et al., 1973年 The true incidence, including particularly cases of nerve deafness with a delay in onset, may be great than this. The anxiety experienced by pregnant mothers not known to have had previous rubelif but who come accidentally into contact with. infection also adds greatly to the problem. Prophys laxis with immunoglobulin though practised for many years is relatively ineffective in preventin

NATIONAL SURVEILLANCE OF CONGENITAL RUBELLA JULY 1971-JUNE 1972

(Dudgeon et al., 1973)

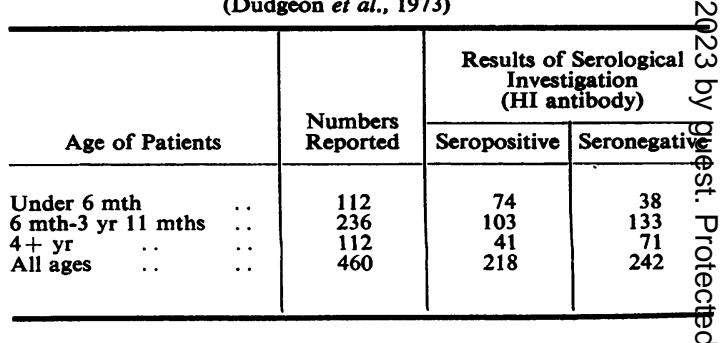


maternal rubella after contact and even in preventing the progress of infection in the mother (Report of the Public Health Laboratory Service Working Party on Rubella, 1970). Congenital rubella may, moreover, occur even though maternal infection is subclinical. Serological tests on the mother who has had contact with rubella now enables a firm statement to be made that she is not at risk if she possesses antibodies and therefore is not likely to transmit the virus to the fetus. It is thus possible to offer termination of pregnancy to the much smaller number of patients who, being seronegative, are susceptible at the time of exposure, and this is current practice. Nevertheless in England and Wales 750 pregnancies were terminated in 1972 because of the risk of congenital rubella. That this should be so in spite of the fact that $85 \%$ of adult women possess rubella antibodies is extraordinary.

Rubella vaccine prepared from living virus attenuated by tissue culture passages was offered to girls in Britain between the ages of 11 and 14 in 1970 and thereafter, and this will ultimately reduce the risk of congenital rubella. The ability to immunize against rubella is indeed remarkable in view of the fact that the virus was cultivated only for the first time in the laboratory in 1962 (Weller and Neva, 1962; Parkman, Buescher, and Artenstein, 1962). But the rate of acceptance of vaccine by girls is sometimes low, and there is a need to help the woman of childbearing age who has not been immunized and may be susceptible to rubella. School-teachers, nursery staff, women doctors, and nurses in children's hospitals or obstetric units are now offered vaccine if a preliminary serological test has shown an absence of antibody. An extension of vaccination to adult women is hindered by the risk of the occurrence of pregnancy shortly before vaccine has been given.

Rubella vaccine may, in fact, be harmless to the fetus, for some healthy babies have been born to women who were vaccinated at a time when it was not known that they were pregnant. However, rubella virus has been recovered from the placenta and products of conception after abortion in vaccinated women (Levine, Edsall, and Bruce-Chwatt, 1974). It is therefore advised that for two months after vaccine has been given to adult women a secure method of contraception should be practised. The early post-partum period is a convenient time for vaccination because of the absence of ovulation after delivery for some weeks and if tests of antenatal serum have shown a lack of antibodies, vaccination after delivery is strongly advised. No attempt, it should be noted, is at present being made to reduce the transmission of virus in the community, though in the USA rubella vaccine is given in infancy to both sexes in an effort to achieve this objective.

\section{INFLUENZA}

A very different picture is presented by influenza which remains undefeated in spite of 41 years of research upon the virus since its first isolation in London (Smith, Andrewes, and Laidlaw, 1933). Epidemics and localized outbreaks continue periodically throughout the world and though vaccines are available either as inactivated or as living attenuated viruses and a limited degree of protection can be given to the individual, no way has yet been found to check the spread of virus in the community. There are many reasons for this failure. The clinical disease itself confers only a short-lived immunity compared, for instance, with that of measles, and immunization must be repeated annually or biennially. Secondly, the susceptibility to infection is not confined to any age-group so that the virus apparently spreads broadly through the community. The problem of conferring communityresistance is therefore very large in scale. Quarantine of whole areas cannot be regarded as a serious measure though there is evidence from the Australian experience in 1918 of its temporary efficacy. Thirdly, the surface antigens of the viruses change periodically so that the viruses current today bear little resemblance to those of former years although they still bear the same internal ribonucleoprotein common in the case of influenza $\mathbf{A}$ to all human and many animal influenza viruses.

Two types of change occur in both influenza A and $B$ viruses, and these involve the haemagglutinin or neuraminidase proteins of the surface. The first is a small change occurring from one epidemic to the next or the next but one, and this is termed 'antigenic drift'. It is believed to occur because viruses multiplying in persons with partially protective antibodies breed out variants less well neutralized by the antibodies to the parent strain. This could be described as a type of phenotypic adaptation. It has been particularly evident in both the haemagglutinin and the neuraminidase of the influenza $A$ viruses of the past five years. The second is a more abrupt and so far an unpredictable change occurring roughly every 10 years with influenza virus $\mathbf{A}$ and less frequently with influenza B. The new virus appears in the world at a particular time and place and because it bears an unfamiliar previously unknown antigen it spreads far and wide, giving rise as it does to large epidemics or to a pandemic. Such large antigenic variations are not found in other human viruses 
and seem to be unique for influenza. Their origin is unexplained in spite of much speculation, particularly as to whether they are truly novel variant strains or simply the viruses of former epidemics re-cycling through the population from an undisclosed reservoir.

A recent view (Kilbourne, 1968) is that the variants arise by genetic recombination between two strains of influenza virus. This phenomenon can be induced in the laboratory by inoculating simultaneously into the same culture system two unrelated influenza viruses possessing different antigens and biological properties such as those of a human and an animal strain. An inhibitor which has a selective action on one of the viruses is added and under suitable cultural conditions some of the progeny of particles which emerge possess different properties from either of the two parent viruses. Thus the antigens and biological properties are exchanged, and from viruses which might be described genetically as $\mathbf{A B}$ and $\mathrm{CD}$ there emerge particles AC and BD. Delbrück and Bailey demonstrated such genetic recombination with bacterial viruses in 1946, and Burnet and Lind accomplished it with influenza viruses in 1951 . Nowadays the technique is used regularly to implant a new antigen on the particles of a well-adapted laboratory influenza $\mathbf{A}$ virus and to produce a rapidly multiplying 'new' virus with the desired antigen or to prepare an attenuated virus suitable for live vaccines.

Pons and Hirst (1968) showed that the RNA of the influenza viruses exists in several distinct segments each of which may code for a single structural protein. A reassortment of the RNA pieces inside the host cell after infection is probably the basis of genetic recombination. Laver and Webster (1973) in Canberra showed that the change in the haemagglutinin from the Asian to the Hong Kong virus involved a rearrangement of the amino-acids in the polypeptide chain, presumably by reason of a change in the base-pairing of the messenger RNA. They found that the light chain of the haemagglutinin of the influenza A/Hong Kong virus closely resembles a portion of the light chain of the haemagglutinin of the A2/Equine virus first recovered from horses in 1963. They suggested that genetic recombination between a human and an avian or mammalian influenza virus might produce a human pandemic virus with an unfamiliar haemagglutinin or neuraminidase. Could genetic interchange between two such viruses occur naturally and, if so, in which milieu-the human or the animal? The question is intriguing but unanswered as yet. An affirmative answer would not explain the almost regular interval of a decade between the emergence of new pandemic human viruses bu then neither does the alternative explanation of. genetic mutation or even the possible reactivatio of a former human strain which has survived fof decades in some hidden human or animal reservoir?

Influenza viruses thus provide one of nature' most jealously guarded secrets and one with profound bearing both upon the epidemiology of the disease and upon the problem of protection by immunization. This is because the virus seed used to prepare either inactivated or live attenuated vaccines must be antigenically close to the virus causing current influenza epidemics. The formulas of the vaccines therefore has to be changed ig conformity with nature's changes, and the desiris to anticipate the viruses of the future is very great. One way to anticipate changes, namely by growing the virus in the presence of antiserum just too wear to prevent infection, has already been exploited for vaccine production at the Pasteur Institute i Paris (Hannoun, 1973). The problem then becomes one of the selection of the correct variant, and though Fazekas de St. Groth (1969) claimed that the relative power of precedence of one virus strain ogepr another could be forecast, it is likely that the method will break down in practice. The detection of natufie' variation at the earliest possible moment by the World Health Organization's world-wide chain of reference laboratories thus remains an essentias guide to the selection of viruses for vaccine pro duction.

It is obvious from these comments that there $i \overline{8}$ much unfinished business in the case of influenzaô. and virology still has to make the contributio which may enable the advantage to be wrested fron? the virus and put into human hands. A disease due to a virus of changing constitution whose trans $\vec{Z}$. mission through the community is not through 8 narrow stream is indeed a formidable opponent.

\section{Smallpox, Yellow Fever and Rabies}

Some may wonder why so far no consideratio has been given to such well-established virus:infections as smallpox, yellow fever, and rabiess For each of these specific vaccines has long been available yet attempts to control their spread have met with varying degrees of success. Smallpox if an historical enemy believed to have been recognizer first in England in 1561 shortly before Queefo Elizabeth I herself contracted the disease. It cease to be endemic in England and Wales in 1935 probably because of a decade of outbreaks of alastrim totalling as many as 10000 cases per year. combined with the effects of infant immunizatiofio 
(Dixon, 1962). Britain has remained free from endemic smallpox for nearly 40 years though subject to imported and frequently virulent smallpox. In spite of the occurrence of 41 separate importations of the virus since 1935 by persons arriving from overseas (Barnes, 1971, unpublished) the subsequent outbreaks have been contained even though mortality among those affected had reached $40 \%$ in some institutions. In the UK imported smallpox can be controlled by a judicious combination of the segregation of patients, the tracing of contacts, their quarantine, and immunization with vaccine lymph. Mass immunization plays little or no part in the control of spread of the virus, and the temporary protection of children by infant vaccination is of little value when less than $40 \%$ of parents accept the procedure. The recent tragic reminder that cultured variola virus is still virulent for man indicates the need to improve our own laboratory handling of the virus. The additional contribution of virological techniques such as electron microscopy has been of inestimable value in the rapid differential diagnosis of imported smallpox in immunized persons, and it played its part in the control of the London outbreak of 1973 (Report of the Committee of Enquiry, 1974).

The work of the World Health Organization in the eradication of smallpox from many countries where it was formerly endemic has been well described by Henderson (1972) and it will not here be repeated. The replacement of mass immunization by a search for cases of smallpox, the tracing of contacts, and the focal use of vaccine indicate the success of a strategy aimed at breaking the transmission of the virus. The limitation of endemic smallpox to five or six countries by 1973 compared with that of 42 countries in 1967 is an eloquent testimony to the success of the WHO eradication campaign (Figs. 3 and 4). The reduced risk of

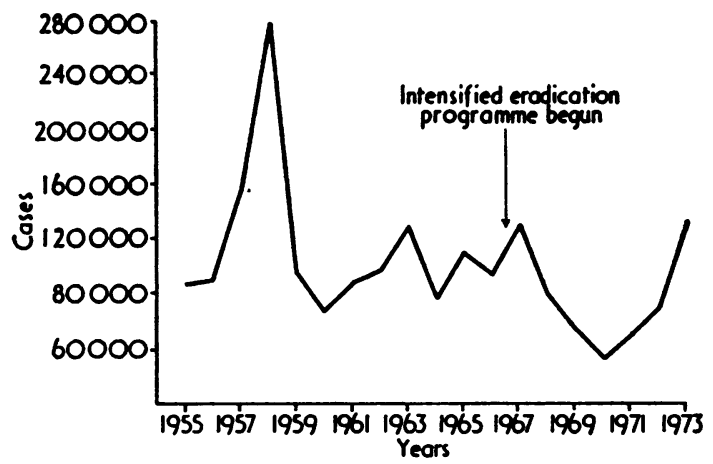

Fig. 3. Smallpox surveillance. Reported world cases, 1955-73, World Health Organization, Geneva.

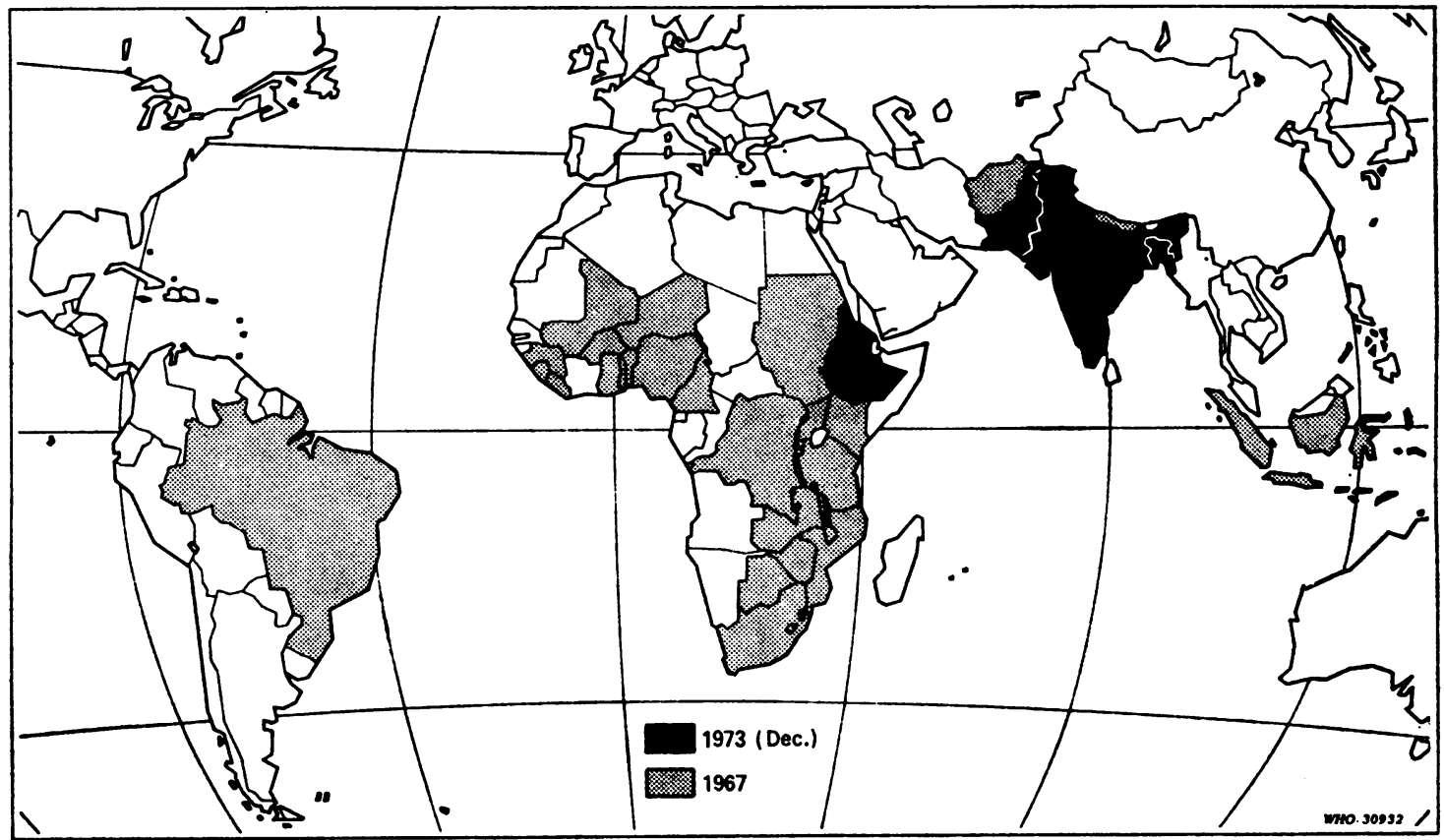

Fio. 4. Smallpox endemic countries, 1967 and 1973. (Weekly Epidemiological Record, 104, 10 May 1974, p. 2). 
imported smallpox has enabled Britain and the USA to discontinue infant immunization which over the past 20 years has proved hazardous, particularly to babies with eczema or immunological deficiencies. Whether this change in policy can or cannot be sustained will depend on the ultimate degree of success in the WHO campaign. The story of smallpox in the past 150 years is a sad commentary on the lack of man's ability to utilize properly the knowledge provided by Jenner's discovery.

Yellow fever is also an uncontrolled disease but this is because of the existence of a jungle cycle of infection involving the virus, monkeys, and mosquitoes. The disease in man is now an accidental zoonosis and one against which the live attenuated vaccine developed at the Rockefeller Institute for Medical Research gives excellent protection. The ability of the virus still to cause widespread epidemics in Africa (Brès, 1971) indicates the essential requirement for mosquito control. The contribution of virology towards disease control must be limited to the protection of the individual so long as an endemic reservoir of virus maintains itself in the animal kingdom.

Rabies, which is also a zoonosis, presents still a sombre picture. We in Britain owe a considerable debt to our island situation for we rely upon the quarantine imposed on imported pets to afford us freedom from this most unpleasant disease. The fact that endemic rabies is still a problem in many countries indicates the unsatisfactory state of control measures. Considerable efforts have been and continue to be made to improve rabies vaccine but so far these have not seemed other than promising (Campbell et al., 1968; Wiktor, 1971). The basic problem of the reservoir of virus in the mammalian kingdom is unsolved.

\section{HePatitis}

It is a relief to turn to the problem of hepatitis which seemed at one time an impregnable disease. The finding of the Australia antigen by the geneticist Blumberg and others in 1965 has opened the door to a truly remarkable voyage of discovery. The realization of the threat posed by human bloodproducts first occurred less than 40 years ago. The ability to detect Australia antigen and to titrate specific serum antibody by increasingly sophisticated methods has widened and is continuing to widen the concept of hepatitis B virus infection (Brotman, Prince, and Godfrey, 1973; Jeffries et al., 1973). Parenteral inoculations with heated serum containing Australia antigen by Krugman and Giles (1973) or with immune globulin containing antibody to hepatitis $B$ virus by
Szmuness and others (1974) are stated to prevent $\stackrel{D}{D}$ serum hepatitis. Much more important is the new ability to detect at least some of the dangerous carriers of the virus and to exclude them as blood donors. This is indeed an unexpected help in the fight against hepatitis, though a reliable system of $\overline{0}$ cultivation of the virus in the laboratory is still $\frac{\mathrm{C}}{\mathrm{C}}$ awaited.

\section{The Promise of Antiviral Chemotherapy}

The very success of antibacterial chemotherapy has, by contrast, emphasized the dismal failure of $\overrightarrow{0}$ many attempts to perfect chemical methods for $\overrightarrow{\vec{\omega}}$ preventing or treating virus infections. Yet the picture is not wholly black for it has now been $\frac{\Phi}{\circ}$ proved that under favourable circumstances certain $\stackrel{?}{?}$ chemical compounds can exert an inhibitory action upon the multiplication of certain viruses. Gale :(1973) has recently commented that the principal $\vec{a}$ objective of successful chemotherapy is the attain- $\frac{\text { ? }}{2}$ ment of a selective action upon a micro-organism. Against the intracellular virus, whose metabolism and energy systems are bound up with those of the host cell, a selective inhibitory action is clearly more difficult to attain than that against an extracellulas 6 bacterium. Yet the multiplication of the virto particle can no longer be regarded as inviolable.

The Cycle of Virus Replication and Antivirai ACTION

There is still only partial knowledge concerning $\stackrel{\square}{\mathbb{D}}$ the march of events within the susceptible host cell $\overrightarrow{\vec{O}}$ after the virus particle has become attached and $\frac{0}{3}$ later engulfed. Within a few minutes of penetration the particles are still visible by the electron microscope within intracytoplasmic vacuoles but then the multiplication cycle enters the phase of eclipse and particles are no longer visible. It is, however, known that the external protein coat is dissolved 3 by the action of an uncoating enzyme which releases the nucleic acid into the interior of the cell's cytoplasm. There now follows the vital $\circ$ process of viral nucleic acid synthesis, often within the nucleus, and the initiation of a messenger RNA for the translation of viral specific structural proteins in the ribosomes. It is not clear why the $\stackrel{N}{\sigma}$ host cell is unable to attack the viral nucleic acid N by means of its nucleases once it is freed from $\mathrm{N}$ its protective protein coat, but this failure is a prerequisite for the virus to be able to survive and 0 multiply. Many, perhaps all, of the biochemical $\frac{}{\Phi}$ processes concerned in the replicative cycle require $\stackrel{?}{+}$ the mediation of enzymes, some of which are known to be viral in origin, such as the RNA-dependent RNA polymerases, which are the subject of intense 
biochemical research at the present time. Multiplication of the viral nucleic acid is followed by reassembly of nucleic acid and protein into a structural entity, and whole particles may then again be visualized in the cytoplasm or nucleus by the electron microscope. Some viruses such as the myxoviruses do not form particles until they lie just beneath the cell membrane of the cytoplasm prior to their release to the exterior.

At present there are available four drugs which Bauer (1973) in his Milroy lecture listed as firstgeneration antiviral substances-methisazone, idoxuridine, cytarabine, and amantadine (Fig. 5). Also there is the tantalizing substance, interferon, which is a natural antiviral secretion.

As all such antiviral compounds have come to light it has become obvious that, for the most part, and unlike antibodies, they do not exert any direct action on virus particles outside the host or in the extracellular phase. Disinfecting agents are known, but none is valuable in the prevention of virus infection which has actually reached the host. The four drugs already mentioned exert their action after the virus particles have become attached and have penetrated the cell membrane. Yet thereafter the resemblance between these compounds ends for it seems probable that the action of each substance is directed at a different point in the replicative cycle (Prusoff and Goz, 1973).

Idoxuridine (5-iodo-deoxyuridine) and cytarabine (cytosine arabinoside) seem to act directly upon the synthesis of viral nucleic acid and they both inhibit the growth of herpes virus and the pox viruses vaccinia and variola. The action of idoxuridine has not been definitely established but it appears to be selectively incorporated into viral DNA and it may perhaps inhibit the enzyme thymidine kinase which is necessary for the synthesis of DNA-thymine. Because it is also inhibitory to mammalian DNA it is toxic if given parenterally, but herpes keratitis can be treated topically with idoxuridine without upsetting the bone marrow. In the serious condition of herpes encephalitis idoxuridine has been given intravenously with relative safety (Buckley and MacCallum, 1967; Nolan, Lauter, and Lerner, 1973). Cytarabine is believed to exert its action by competitive inhibition of DNA synthesis for it is a pyrimidine nucleoside. It has been used in the treatment of herpes encephalitis (Chow et al., 1973), smallpox (Hossain et al., 1972; Dennis et al., 1974) and disseminated
DRUG

Doxuidone

CYTARABNE

METHSAZONE

MMANTADNE
FORMULA

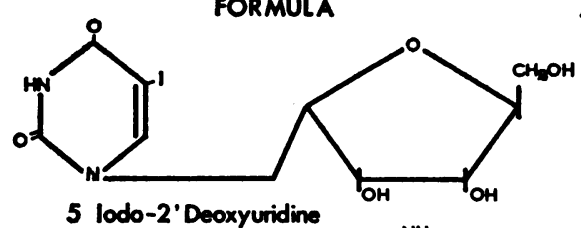

5 lodo-2' Deoxyuridine
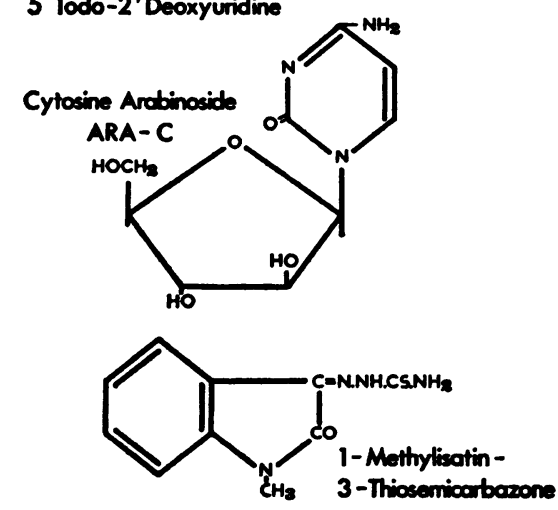

VACCNA

VAPIOLA

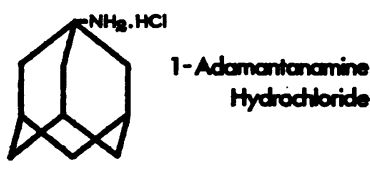

ANTIVIRAL ACTION

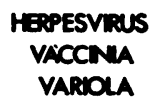

HERPESVIIUS

VARiOLA

DISSEMNATED

ZOSTER

Fig. 5. First-generation antiviral compounds (modified after Bauer (1973)). 
zoster but results have not been uniformly successful, in part because of its inherent toxicity (Stevens et al., 1973).

Methisazone (5-methyl-isatin 3-thiosemicarbazone) has probably been given to more persons than either idoxuridine or cytarabine. It is actively inhibitory to neurovaccinia virus in mice by an action which has eluded exact definition. It is believed to interfere with the function of protein synthesis in the ribosome by the vaccinia messenger RNA without actually preventing viral DNA synthesis (Bauer, 1972). Its use in man is controversial though it is relatively non-toxic. Successful prophylaxis of smallpox in India was obtained by Bauer et al. (1969) in smallpox contacts but Heiner and others (1971) had less satisfactory results. Although some would suggest its use routinely in disseminated vaccinia or in smallpox contacts, the degree of benefit in these conditions has not been established for certain, and treatment of established disease is a very different matter from prophylaxis.

Amantadine (1-adamantanamine hydrochloride), which was empirically discovered to have an antiviral action on influenza virus $A$, was originally thought to prevent cell penetration (Grunert, McGahen, and Davies, 1965). Though it slows down this process it has also been found to inhibit the uncoating of influenza virus $A$ within the cell (Kato and Eggers, 1969; Long and Olusanya, 1972). Its action is remarkably specific for it is inactive against influenza virus B and exhibits only weak action against other viruses such as rubella. Clinical trials have shown that it has undoubted chemoprophylactic effects against influenza A (Togo, Hornick, and Dawkins, 1968; Galbraith et al., 1969a; Nafta et al., 1970). It is more active when the population has had experience of the particular antigenic variant than upon its first introduction (Galbraith et al., 1969b; Oker-Blom et al., 1970), and it has some action of a therapeutic character even after clinical influenza has developed (Togo et al., 1970; Galbraith et al., 1973). The possible production of even more active molecules from amantadine has been less successful than had been hoped though rimantadine (Dawkins et al., 1968) and spiro-adamantane-pyrrolidine maleate (Beare, Hall, and Tyrrell, 1972) are compounds with enhanced anti-influenzal properties. No large-scale use of amantadine has been undertaken perhaps because of its psychotropic effects.

The above instances of antiviral action indicate that the present phase is one of jostling between empirical and logical research. The discovery that viruses possess specific enzymes concerned with nucleic acid synthesis which differ from those of the cell at first appears to afford a rational basis for selective chemotherapy. Oxford (1973) has recently found that the RNA-dependent RNApolymerase or transcriptase enzymes of both influenza $A$ and $B$ viruses are inhibited by the chelating agent selenocystamine and has speculated upon the presence of metallic atoms in the enzymes. Subak-Sharpe, Timbury, and Williams (1969) showed that rifampicin binds to nucleic acid polymerase and inhibits the assembly of pox virus particles. Yet this action is reversible and vaccinia virus rapidly acquires resistance to its inhibitory effect (Moss et al., 1969; Moss, Rosenblum, and Grimley, 1971). It appears that for the present there is still much more fundamental work to be done before a truly logical basis of virus chemotherapy will have been established. Nor can one be satisfied by the prospect of a relatively specific action of synthetic antiviral compounds though this does not hold for interferon. It is perhaps enough to be able to say that there is now convincing evidence that there is no absolute barrier to the formulation of drugs for the prevention or treatment of human virus diseases.

\section{The TANTAlizing ExPERIENCE OF INTERFERON}

Interferon appeared at first to possess idea ov properties for antiviral action. It is a diffusible. protein produced directly by the mammalian cell after infection or treatment by various substances (Isaacs and Lindenmann, 1957; Isaacs, Cox and Rotem, 1963) and is completely non-toxic. It has a broad spectrum of activity against different viruses and therefore must have a mode of action unrelated to virus-specific enzymes and protein. Yet it has serious disadvantages. Preformed interferon is only active if given before the virus infection has advanced, and it is an essentially prophylactic agent. Secondly, the interferon proteins derived from different mammalian and avian host cells exhibit some degree of homologous specificity of action, and a human interferon such as that prepared in leucocytes is much more active in human infections than a mammalian interferon. Thirdly, a highly potent preparation is needed for topical use and is difficult to manufacture.

The use of human leucocyte interferon against Hong Kong influenza in large-scale field trials in the USSR was reported in 1969 by Soloviev. Merigan and others (1973) have recently been successful with intranasal interferon in volunteers against experimental rhinovirus infections. The recent report from Sweden ( Shström et al., 1974) of the use of human leucocyte interferon in children with acute leukaemia to treat zoster and to prevent other intercurrent viral infections while maintaining remission by cytostatic drugs is an indication of its 
potential. Because of the limitations of preformed interferon the idea of inducing interferon in vivo by treating the host led to experiments with polyribonucleotides such as the complex known as poly i.c. (polyriboinosinic-polyribocytidylic acid). This substance induces interferon in laboratory cultures and in experimental animals (Hill, Baron, and Chanock, 1969) but is toxic. It has some action in prevention of rhinovirus infections when used topically in the respiratory tract (Hill et al., 1972) and so has a complex derivative of propanediamine which also induces interferon (Panusarn $e t$ al., 1974). Double-stranded RNAs, such as the fungal mycophage contaminant found in penicillium cultures, are highly potent inducers but are unfortunately toxic. The induction of interferon protein by such substances is thought to be by an action upon the host DNA causing the release of an interferon messenger active in the ribosomes (Grossberg, 1972). Such a complex action appears almost sublimely designed to counter the threat posed by viruses to the mammalian cell.

\section{CONCLUSION}

It is timely in these concluding remarks to remind ourselves of the broad scene presented by virology at the present time. Beginning as a branch of bacteriology, and still regarded as part of microbiology, virology has contributed not only to the conquest of human and animal disease but to the science of biology as a whole. If it now is regarded as a science in its own right, it would not be mischievous to recall that Jenner made his first observations upon milkmaids with cowpox with little realization that he was embarking upon applied virological research. So too was Pasteur when he sought to attempt to attenuate the virulence of the unknown cause of rabies. In our day it is popular to draw distinctions between basic and applied research rather than to emphasize the interplay which should constantly exist between the two. At least physicians should be encouraged to refute the argument that clinical research is of no consequence because it may seem to make no impact upon the immediate problems of human disease. Nor should they be sceptical of the contribution from molecular biochemists utilizing virology as a method for interpreting the inner life of the cell. Molecular virology of this sort may one day make as great a contribution to the conquest of human disease as has immunization in our own time.

Yet it is necessary to adopt a defensive attitude over one aspect of virology. All of us who are practitioners tend to look upon the laboratory in terms of its contribution to diagnosis, and in this respect virology at present poses a dilemma. On the one hand, the cultural methods now available enable the laboratory to recover viruses from patients with many of the common self-limited infections. For the most part these viruses are the cause of these infections. On the other hand, exact virological diagnosis seldom offers the clinician an opportunity to remedy the clinical situation or to prevent the spread of infection in the community. Exceptionally the laboratory may determine practice as by the direct demonstration of variola virus, the proof of maternal rubella or the revelation of the Australia antigen. But one needs to be careful at present to safeguard the virologist from much fruitless work of a retrospective character in order that more fundamental questions may be answered. This situation would change should antiviral chemotherapy become available and depend upon rapid diagnosis.

Finally, may I ask the rhetorical question posed by all Harveian orators concerning their obedience to Harvey's injunction to encourage all Fellows and Members to search and study out the secrets of nature by experiment? Harvey was a biologist in its full sense and he could not have failed to be fascinated by the revelation of the virus as a biological fragment. Here is the virus originating from obscurity, inserting itself into the cells of other living matter, and undergoing multiplication into fragments identical with itself. Whether found in plant, bacterium, insect or mammal the virus holds the key to its own reproduction-a statement which surely would have delighted the author of De Generatione. Truly, nature's secrets have the power to dazzle and to stimulate as much today as in the past centuries. Much has been learnt, and much more remains to be revealed.

\section{REFERENCES}

Åhström, L., Dohlwitz, A., Strander, H., Carlström, G., and CANTELL, K. (1974). Interferon in acute leukaemia in children. Lancet, $1,166$.

Andrewes, C. H. and Pereira, H. G. (1972). Viruses of Vertebrates, 3rd edition. Ballière Tindall, London.

BADHAM, J. (1835). Paralysis in childhood. Four remarkable cases of suddenly induced paralysis in the extremities. London Medical Gazette, 17, 215.

BARNeS, J. (1971). Present risk of importation of smallpox into the U.K. (Report to the Joint Committee on Vaccination and Immunization of the Department of Health (Unpublished).

BAUER, D. J. (1972). Chemotherapy of Virus Diseases, volume I, p. 35. International Encyclopaedia of Pharmacy and Therapeutics. Section 61. Pergamon Press, Oxford. 
(1973). Antiviral chemotherapy: The first decade. Brit. med. J., 3, 275.

—, Vincent, L. St., Kempe, C. H., Young, P. A., and Downie, A. W. (1969). Prophylaxis of smallpox with methisazone. Amer. J. Epidem., 90, 130.

Beare, A. S., Hall, T. S., and TYrRell, D. A. J. (1972). Protection of volunteers against challenge with A/Hong Kong/68 influenza virus by a new adamantane compound. Lancet, 1, 1039.

Blumberg, B. S., Alter, H. J., and Visnich, S. (1965). Clinical science: "new" antigen in leukemia sera. J. Amer. med. Ass., 191, 541.

Brès, P. (1971). The problem of yellow fever in Africa. International Conference on Vaccines against Viral, Rickettsial and Bacterial Diseases of Man, 1970 Pan. Amer. Hlth Org. sci. Publ., 226, p. 25.

Brotman, B., Prince, A. M., and Godfrey, H. R. (1973). Role of arthropods in transmission of hepatitis $B$ virus in the tropics. Lancet, 1, 1305.

Buckley, T. F. and MacCallum, F. O. (1967). Herpes simplex virus encephalitis treated with idoxuridine. Brit. med. J., 2, 419.

Bulloch, W. (1938). The History of Bacteriology. Oxford University Press, London.

BurNet, F. M. (1973). Influenza-the disease. Med. $J$. Aust., Suppl. 1, 3.

- and LIND, P. E. (1951). A genetic approach to variation in influenza viruses. 3. Recombination of characters in influenza virus strains used in mixed infections. J. gen. Microbiol., 5, 59.

Campbell, J. B., Kaplan, M. M., Koprowski, H., KuWERT, E., SOKol, F., and WikTor, T. J. (1968). Present trends and future in rabies research. Bull. Wld Hlth Org., 38, 373.

Chow, A. W., Ronald, A., Fiala, M., Hryniuk, W., Weil, M. L., Geme, J. St., Jnr., and Guze, L. B. (1973). Cytosine arabinoside therapy for herpes simplex encephalitis-clinical experience with six patients. Antimicrob. Agents and Chemotherapy, 3, 412.

Cossart, Y. E. and Whitehouse, C. E. (1973). Genetic marker tests of polioviruses isolated in the United Kingdom between 1965 and 1973. Proc. 14th Symposium on Poliomyelitis, Ankara, 1973, (In press).

Dawkins, A. T., Jnr., Gallager, L. R., Togo, Y., HoRNICK, R. B., and HARRIS, B. A. (1968). Studies on induced influenza in man. II J. Amer. med. Ass., 203, 1095.

Delbrück, M. and BaileY, W. T. (1946). Induced mutations in bacterial viruses. Cold. Spr. Harb. Symp. quant. Biol., 11, 55.

Dennis, D. T., Doberstyn, E. B., Awoke, S., Royer, G. L., Jnr., and RENIS, H. E. (1974). Failure of cytosine arabinoside in treating smallpox. Lancet, 2, 377.

Dixon, C. W. (1962). Smallpox. J. \& A. Churchill, London.
DOBell, C. (1932). Antony Van Leeuwenhoek and hif "Little Animals". John Bale, Sons and Danielsson? London.

Dudgeon, J. A., Peckham, C. S., Marshall, W. C. Smithells, R. W., and Sheppard, S. (1973). Nationa Congenital Rubella Surveillance Programme. Healthe Trends, 5, 75.

Enders, J. F., Katz, S. L., Milovanović, M. V., an $\overline{\frac{\delta}{7}}$ Holloway, A. (1960). Studies on an attenuated measles virus vaccine. New Engl. J. Med., 263, 153.

and Peebles, T. C. (1954). Propagation in tissue cultures of cytopathogenic agents from patients witl $\vec{P}$ measles. Proc. Soc. exp. Biol. (N.Y.), 86, 277

_, Weller, T. H., and RobBins, F. C. (1949) Cultivation of the Lansing strain of poliomyelitis virus in cultures of various embryonic tissues. Science $\frac{\rho}{2}$ 109, 85.

FazeKaS de ST. GRoth, S. (1969). New criteria for thè selection of influenza vaccine strains. Bull. Wld HlthOrg., 41, 651.

Fracastorius, G. (1546). De Contagione et Contagiosis Morbis et eorum Curatione. Liber 3, translated by W及 C. Wright (1930). G. P. Putman \& Sons, New York

Francis, T., Jnr., Napier, J. A., Voigt, R. B. Hemphill, F. M., WenNer, H. A., Korns, R. F.仓 Boisen, M., Tolchinsky, E., and Diamond, E. g्र (1957). Evaluation of the 1954 Field Trial of Potio myelitis Vaccine. The National Foundation for Infandile Paralysis. Edwards Bros., Ann Arbor, USA.

Galbraith, A. W., Oxford, J. S., Schild, G. C., anch WATSON, G. I. (1969a). Protective effect of 1-adamant? anamine hydrochloride on influenza $A 2$ infection in the family environment. Lancet, 2, 1026.

- - - - and - (1969b). Study of 1-adamantanamine hydrochloride used prophylacti? cally during the Hong Kong influenza epidemic in the family environment. Bull. Wld Hlth Org., 41, 677 -, Schild, G. C., Potter, C. W., and Watson, G. I (1973). The therapeutic effect of amantadine in influenza occurring during the winter of 1971-72. assessed by double-blind study. J. roy. Coll. gen Practit., 23, 34.

Gale, E. F. (1973). Perspectives in chemotherapy. Brito med J., 4, 33.

GREGG, N. MCA. (1941). Congenital cataract following German measles in the mother. Trans. Ophthal. Soc Aust., 3, 35.

Grossberg, S. E. (1972). The interferons and theif inducers: molecular and therapeutic considerations N New Engl. J. Med., 287, 13, 79, 122.

GrunerT, R. R., McGaheN, J. W., and Davies, W. L (1965). The in vivo antiviral activity of 1-adamante anamine (amantadine). 1. Prophylactic and theraon peutic activity against influenza viruses. Virology 26, 262.

HaNNOUN, C. (1973). Un nouveau pas dans $1 \frac{0}{\oplus}$ vaccination antigrippale. Nouv. Presse Méd., 2, 1199 
HARVey, W. (1653). De Generatione AnimaliumAnatomical exercitations concerning the generation of living creatures. Exercise 49, p. 254. James Young, London.

HeINE, J. (1840). Beobachtungen über Lähmungszustände der unterem Extremitäten und deren Behandlung. Köhler, Stuttgart.

Heiner, G. G., fatima, N., Russell, P. K., HaAse, A. T., Ahmad, N., Mohammed, N., Thomas, D. B., MaCK, T. M., Khan, M. M., Knatterud, G. L., Anthony, R. L., and MCCRUMB, F. R. Jnr. (1971). Field trials of methisazone as a prophylactic agent against smallpox. Amer. J. Epidem., 94, 435.

Henderson, D. A. (1972). Epidemiology in the global eradication of smallpox. Int. J. Epidem., 1, 25.

Heyworth, B. (1973). Pathogenesis of measles. Brit. med. J., 3, 693.

Hill, D. A., Baron, S., and Chanock, R. M. (1969). The effect of an interferon inducer on influenza virus. Bull. Wld Hlth Org., 41, 689.

- - - Perkins, J. C., Worthington, M., van ..KIRK, J. E., Mills, J., Kapikian, A. Z., and Chanock, R. M. (1972). Evaluation of an interferon inducer in viral respiratory disease. J. Amer. med. Ass., 219, 1179.

Horstmann, D. M. (1952). Discussion of symposium 4. Poliomyelitis: Papers and discussion presented at the Second International Poliomyelitis Conference Copenhagen 1951, p. 336. Lippincott, Philadelphia.

Hossain, M. S., Foerster, J., Hrynuik, W., IsRaels, L. G., Chowdhury, A. S., and Biswas, M. K. (1972). Treatment of smallpox with cytosine arabinoside. Lancet, 2, 1230.

HuXley, T. H. (1870). Presidential address, British Association Advancement of Science. Nature, 2, 400.

IsaAcs, A., Cox, R. A., and Rotem, Z. (1963). Foreign nucleic acids as stimulus to make interferon. Lancet, 2, 113.

- and LindenmanN, J. (1957). Virus interference. 1, The interferon. Proc. roy. Soc., B, 147, 258.

Jefrries, D. J., James, W. H., JefFeriss, F. J. G., MAcLeod, K. G., and WillcoX, R. R. (1973). Australia (hepatitis-associated) antigen in patients attending a venereal disease clinic. Brit. med. J., 2, 455.

JeNNER, E. (1798). An Inquiry into the Causes and Effects of the Variolae Vaccinae, London. Republished 1896. Cassell, London.

KATO, N. and EgGers, H. J. (1969). Inhibition of uncoating of fowl plague virus by 1-adamantanamine hydrochloride. Virology, 37, 632.

Keynes, G. (1966). The Life of William Harvey, p. 247. The Clarendon Press, Oxford.

KILBOURNe, E. D. (1968). Recombination of influenza A viruses of human and animal origin. Science, 160, 74.
Kling, C., Pettersson, A., and Wernstedt, W. (1912). Experimental and pathological investigation. 1. The presence of the microbe of infantile paralysis in human beings. Trans. by A. V. Rosen. Report to the 15th International Congress on Hygiene and Demography, Washington. Communications, State Medical Institute, Stockholm, 3, 5.

Krugman, S. and Giles, J. P. (1973). Viral hepatitis, Type B (MS-2-strain). New Engl. J. Med., 288, 755.

LANDSTeIner, K. and PopPer, E. (1908). Mikroscopische Präparate von einem menschlichen und zwei Affenrückenmarken. Wien. klin. Wschr., 21, 1830.

LAVER, W. G. and Webster R. G. (1973). Studies on the origin of pandemic influenza. III. Evidence implicating duck and equine influenza viruses as possible progenitors of the Hong Kong strain of human influenza. Virology, 51, 383.

van LeeuWenhoek, A. (1686). Letter. Philosoph. Trans. Roy. Soc., 16, 1121.

Levine, M. M., Edsall, G., and Bruce-Chwatt, L. J. (1974). Live-virus vaccines in pregnancy. Risks and recommendations. Lancet, 2, 34.

LoNG, W. F. and Olusanya, J. (1972). Adamantanamine and early events following influenza virus infection. Arch. Virusforsch., 36, 18,

LwoFf, A. (1957). The concept of virus. J. gen. Microbiol., $17,239$.

Medin, O. (1891). Ueber eine Epidemie von spinaler Kinkerlähmung. Verh. $X$ internat. med. Kongr., 1890 , 2, Abt. 6, 37.

Merigan, T. C., Reed, S. E., Hall, T. S., and Tyrrell, D. A. J. (1973). Inhibition of respiratory virus infection by locally applied interferon. Lancet, 1, 563 .

MilleR, D. L. (1964). Frequency of complications of measles, 1963. Brit. med. J., 2, 75.

—, REID, D., and Diamond, J. R. (1970). Poliomyelitis surveillance in England and Wales 1965-68. Publ. Hlth, London, 84, 265.

Miller, H. G., Stanton, J. B., and Gibbons, J. L. (1956). Para-infectious encephalomyelitis and related syndromes. Quart. J. Med., 25, 427.

MorLey, D. (1969). Severe measles in the tropics. Brit. med. J., 1, 297.

Moss, B., Rosenblum, E. N., and Grimley, P. M. (1971). Assembly of virus particles during mixed infection with wild-type vaccinia and a rifampicin-resistant mutant. Virology, 45, 135.

$\longrightarrow$, - KATZ, E., and Grimley, P. M. (1969). Rifampicin: a specific inhibitor of vaccinia virus assembly. Nature (Lond.), 224, 1280.

Nafta, I., Turcano, A. G., Braun, I., Companetz, W., Simionescu, A., Birt, E., and Florea, V. (1970). Administration of amantadine for the prevention of Hong Kong influenza. Bull. Wld Hlth Org., 42, 423

Nolan, D. C., LAUTer, C. B., and LeRner, A. M. (1973). Idoxuridine in herpes simplex virus (Type 1). encephalitis. Ann. intern. Med., 78, 243. 
Nonoyama, M. and Pagano, J. S. (1973). Homology between Epstein-Barr virus DNA and viral DNA from Burkitt's lymphoma and nasopharyngeal carcinoma determined by DNA-DNA reassociation kinetics. Nature (Lond.), 242, 44.

Orer-Blom, N., Hovi, T., Leinikxi, P., Palosuo, T., Pettersson, R., and SunI, J. (1970). Protection of man from natural infection with influenza A2 Hong Kong virus by amantadine. A controlled field trial. Brit. med. J., 3, 676.

OxFoRD, J. S. (1973). An inhibitor of the particleassociated RNA-dependent RNA polymerase of influenza A and B viruses. J. gen. Virol., 18, 11.

PanUm, P. L. (1940). Observations made during the epidemic of measles on the Faröe Islands in the year 1846. Delta Omega Society, American Public Health Association, New York.

Panusarn, C., Stanley, E. D., Dirda, V., Rubenis, M., and JACKson, G. G. (1974). Prevention of illness from rhinovirus infection by a topical interferon inducer. New Engl. J. Med., 291, 57.

Parkman, P. D., Buescher, E. L., and Artenstein, M. S. (1962). Recovery of rubella virus from Army recruits. Proc. Soc. exp. Biol. (N.Y.), 111, 225.

Pasteur, L., Chamberland, C., Roux, E., and Thuillike, L. F. (1881). Sur la rage. C. R. Acad. Sci. (Paris), 92, 1259.

Paul, J. R. (1938). Clinical epidemiology. J. clin. Invest., 17, 539.

(1971). A history of poliomyelitis. Yale Studies in the History of Science and Medicine, p. 6. Yale University Press, New Haven and London..

Pons, M. W. and Hirst, G. K. (1968). Polyacrylamide gel electrophoresis of influenza virus RNA. Virology, 34, 386.

Prusoff, W. H. and Goz, B. (1973). Potential mechanisms of action of antiviral agents. Fed. Proc., 32, 1679.

Reid, D., Bell, E. J., Grist, N. R., and Wilson, T. S. (1973). Poliomyelitis: a gap in immunity. Lancet, 2, 899.

Report of the Committee of Inquiry into the Smallpox outbreak in London, April 1973. Cmnd 5626 (1974). HMSO, London.

Report of the Measles Vaccines Committee to the Medical Research Council. Vaccination against measles: a Clinical trial of live measles vaccine given alone and live vaccine preceded by killed vaccine. -(1966). Brit. med. J., 1, 441.

-(1968). Brit. med. J., 2, 449.

-(1971). Practitioner, 206, 458.

-(1972). Unpublished.

Report of the Public Health Laboratory Service Working Party on Rubella. (1970). Studies of the effect of immunoglobulin on rubella in pregnancy. Brit. med. J., 2, 497.
Rhazes (Ar-Rázi) (1848). A Treatise on the Smallpor and Measles. Sydenham Society, London.

RODEN, A. T. (1973). Effect of vaccination on the incidence of measles and on the immunity of the chiff: population in England and Wales. Unpublished report to the Joint Committee on Vaccination and Immunizas tion, Department of Health and Social Securit London.

SCHWARZ, A. J. F. (1964). Immunization against measle? Development and evaluation of a highly attenuate live measles vaccine. Ann. paediat., 202, 241.

Skelton, J., Schild, G. C., and Stuart-Harris, C. 任 (1966). Screening of children's sera for antibodies to polioviruses. Month. Bull. Minist. Hith Lab. Ser命 25, 191.

SmITH, J. W. G. (1974). Unpublished data: Public Healifg Laboratory Service, England and Wales.

Smith, W., Andrewes, C. H., and Laidlaw, P. $\dot{\vec{B}}$ (1933). A virus obtained from influenza patients? Lancet, 2, 66.

Soloviev, V. D. (1969). The results of some controllod observations on the prophylaxis of influenza wi interferon. Bull. Wld Hlth Org., 41, 683.

Stanley, W. M. (1935). Isolation of a crystafines protein possessing the properties of tobacco-mosaic virus. Science (N.Y.), 81, 644.

Statutes of the College of Physicians (1630). Oräers against the Plague. Advice set down by the College of Physicians by His Majesties Special Command. Barker and J. Bill, London.

Stevens, D. A., Jordan, G. W., Waddell, T. F., an Merigan, T. C. (1973). Adverse effect of cytosine arabinoside on disseminated zoster in a controlled trial. New Engl. J. Med., 289, 873.

StUART-HARRIs, C. H. (1962). Viruses of human disease Brit. med J., 1, 1779.

Subak-Sharpe, J. S., Timbury, M. C., and Williang, J. F. (1969). Rifampicin inhibits the growth of songe mammalian viruses. Nature (Lond.), 222, 341.

Sutherland, I. and Fayers, P. M. (1971). Effect of measles vaccination on incidence of measles in the community. Brit. med. J., 1, 698.

Szmuness, W., Prince, A. M., Goodman, M., Ehricho C., Pick, R., and Ansari, M. (1974). Hepatitis $\mathscr{B}^{\circ}$ immune serum globulin in prevention of nots parenterally transmitted hepatitis B. New Engl.J. Med W 290, 701.

TODARO, G. J. (1973). Detection and characterization RNA tumour viruses in normal and transformed celf Perspective Virol., 8, 81. Academic Press, New Yo and London.

Togo, Y., Hornick, R. B., and Dawkins, A. T., JnR (1968). Studies on induced influenza in man. J. Amer. med. Ass., 203, 1089. 
Feliti, V. J., Kaufman, M. L., Dawkins, A. T., Jnr., KILPE, V. E., and ClAGHORN, J. L. (1970). Evaluation of therapeutic efficacy of amantadine in patients with naturally occurring A2 influenza. J. Amer. med. Ass., 211, 1149.

Trask, J. D., Vignec, A. J., and Paul, J. R. (1938). Isolation of poliomyelitis virus from human stools. Proc. Soc. exp. Biol. (N.Y.), 38, 147.

TYLER, H. R. (1957). Neurological complications of rubella (measles). Medicine (Baltimore), 36, 147.
Weller, T. H. and Neva, F. A. (1962). Propagation in tissue culture of cytopathogenic agents from patients with rubella-like illness. Proc. Soc. exp. Biol. (N.Y.), 111, 215.

WikTOR, T. J. (1971). New vaccines and the future of rabies prophylaxis. Int. Conf. Appl. Vaccines against Viral, Rickettsial and Bacterial Diseases of Man 1970, Pan. Amer. Hlth Org. Sci. Publ., 226, p. 66.

Requests for reprints to: Professor Sir Charles StuartHarris, Faculty of Medicine, University of Sheffield Medical School, Beech Hill Road, Sheffield S10 2RX. 